\title{
Diets of Overwintering Caribou, Rangifer tarandus, Track Decadal Changes in Arctic Tundra Vegetation
}

\author{
KYLE Joly ${ }^{1,3}$, M. JEANIE COLE ${ }^{1}$, and RANDi R. JANDT ${ }^{2}$ \\ ${ }^{1}$ Bureau of Land Management, Fairbanks District Office, 1150 University Avenue, Fairbanks, Alaska 99709 USA \\ ${ }^{2}$ Bureau of Land Management, Alaska Fire Service, Fort Wainwright, Alaska 99703 USA \\ ${ }^{3}$ Current address: National Park Service, Gates of the Arctic National Park and Preserve, 4175 Geist Road, Fairbanks, Alaska \\ 99709 USA; Corresponding author e-mail: Kyle_Joly@nps.gov
}

Joly, Kyle, M. Jeanie Cole, and Randi R. Jandt. 2007. Diets of overwintering Caribou, Rangifer tarandus, track decadal changes in Arctic tundra vegetation. Canadian Field-Naturalist 121(4): 379-383.

We compared winter diets of Western Arctic Herd Caribou (Rangifer tarandus) from 1995/1996 and 2005 using microhistological fecal analysis on samples collected at paired permanent vegetation transects. Changes in the diets of Caribou followed the same trends as vegetative changes documented in long-term studies in northwestern Alaska. Lichens were significantly less prevalent on the landscape and in the winter diets of Caribou between 1995/1996 and 2005, while graminoids (grasses and sedges) were significantly more prevalent. Dramatic changes are forecasted for Arctic ecosystems under global warming scenarios which may continue the trend of declining lichens in northwestern Alaska and in the diet of Western Arctic Herd Caribou. The question of whether or not the altered diet will affect the population dynamics of this herd remains unresolved.

Key Words: Caribou, Rangifer tarandus, diet, fecal analysis, climate change, habitat, Western Arctic Herd.

The Western Arctic Herd (WAH), with nearly 500000 Caribou (Rangifer tarandus) as of 2003, is currently one of the largest in the world. Population level records of the herd date back to 1970 when the herd was estimated to be 242000 Caribou (Dau 2005a). The WAH crashed between 1970 and 1976, falling to 75000 Caribou (Dau 2005a). It rebounded quickly from this population low, growing at an annual rate of about $13 \%$ for more than a decade and reached 416 000 Caribou in 1990 (Dau 2005a). Growth has continued, albeit at a more measured $1 \%$ average annual growth rate, reaching 490000 in 2003 (Dau 2005a). The WAH is an important subsistence resource for approximately 30 villages in northwestern Alaska (Dau 2005a) which harvest nearly $500000 \mathrm{~kg}$ of meat from this herd annually (Valkenburg 1994). Changes to the range on which this herd depends is therefore a subject of interest to the inhabitants of the region, sport hunters, wildlife enthusiasts and land managers. Our goal was to monitor changes in the vegetative characteristics of the herd's winter range, quantify the diets of Caribou utilizing this range, and track changes that have occurred since the previous decade.

The effects of global climate change are currently being expressed in the Arctic. Already documented are warming temperatures, melting glaciers, reduction of pack ice extent, shrinking lakes, and alteration of vegetative communities (Hansen et al. 1999; Serreze et al. 2000; Sturm et al. 2001; Smith et al. 2005). In terms of arctic vegetation specifically, lichen abundance is predicted to decline while vascular shrubs and graminoids (grasses and sedges) may increase (Chapin et al. 1995; Cornelissen et al. 2001; Walker et al. 2006). Though Caribou grazing and trampling have been im- plicated as major factors in reduced lichen abundance (Moser et al. 1979; Messier et al. 1988; Arseneault et al. 1997; Joly et al. 2007b), climate change may further exacerbate declines. Lichens are thought to be a critical component of the winter diet of large, migratory herds in northern North America (White et al. 1981; Klein 1991). Poor winter range conditions can affect body condition, fetal growth, calf birth weights, milk production, and calf growth rates (White 1983; Parker et al. 2005). Declines in these vital signs could result in reduced herd productivity; therefore, changes in vegetation has the potential to affect Caribou populations and people who depend on them.

\section{Methods}

Joly et al. (2007b) investigated 25 permanent vegetation transects, originally deployed in 1981, in 1995 and $1996(1995 / 1996)$ and then reexamined them in 2005. All transects were located in and around the Buckland River valley, which is entirely within the core winter range of the WAH in northwestern Alaska, USA (Dau 2005a; Joly et al. 2007a). Joly et al. (2007b) laid out a sampling frame $(1.0 \times 0.5 \mathrm{~m})$ every $4 \mathrm{~m}$ along the $50-\mathrm{m}$ transect for a total of 12 frames per transect. The frame was strung every $10 \mathrm{~cm}$ along both axes, which created 50 intercepts. The first species observed under the intercept was recorded and a percent cover was derived. Each species was assigned to one of following categories: lichen, graminoid, moss, shrub, or forb (see Joly et al. 2007b for more details). Un-vegetated observations (e.g., rocks) were assigned to a different category.

We collected composite fecal samples at 24 of these same transects both in 1995/1996 and in 2005. At one 
TABLE 1. Changing percent cover of various vegetative categories comprising the core winter range of the Western Arctic Herd, northwestern Alaska, USA from 1995/1996 and 2005 (adapted from Joly et al. 2007b). Note that percentages do not tally to $100 \%$ because the un-vegetated class is not reported here.

\begin{tabular}{lcccccc}
\hline \hline Class & $1995 / 1996$ & 2005 & Change & $\mathrm{P}$ & $\mathrm{T}$ & $\mathrm{df}$ \\
\hline Lichens & 16.8 & 12.5 & - & 0.004 & 3.21 & 24 \\
Graminoids & 25.3 & 31.9 & + & 0.001 & 4.39 & 24 \\
Moss & 5.9 & 6.1 & $/$ & 0.673 & 0.43 & 24 \\
Shrubs & 30.1 & 32.8 & + & 0.045 & 2.12 & 24 \\
Forbs & 5.9 & 3.9 & - & 0.001 & 3.86 & 24 \\
\hline \hline
\end{tabular}

TABLE 2. Changing percentage of various vegetative categories in the (uncorrected) diets of Caribou in the Western Arctic Herd, northwestern Alaska, USA from 1995/1996 and 2005.

\begin{tabular}{lcccccc}
\hline \hline Class & $1995 / 1996$ & 2005 & Change & P & T & df \\
\hline Lichens & 58.5 & 50.6 & - & 0.001 & 3.73 & 23 \\
Graminoids & 15.0 & 21.6 & + & 0.002 & 3.53 & 23 \\
Moss & 16.1 & 14.5 & $/$ & 0.351 & 0.95 & 23 \\
Shrubs & 7.2 & 8.6 & $/$ & 0.169 & 1.42 & 23 \\
Forbs & 3.2 & 4.5 & $/$ & 0.155 & 1.47 & 23 \\
\hline \hline
\end{tabular}

of the 25 transects we were unable to locate enough samples to conduct analyses. Each composite sample contained about 20 winter (based on form and herd distribution) fecal pellets collected from different pellet groups - one pellet per group. In a few cases, when 20 individual pellet groups were not available, we took two pellets from each group. The samples were frozen and then shipped to a laboratory (see Acknowledgments) for composition analysis. All samples from both sampling periods were analyzed by the same technician during the same session to reduce potential sources of error (see Russell et al. 1993). The relative density of plant fragments was based on 100 fields per sample.

The uncorrected results were compared to changes in vegetative cover determined from the permanent transects. The uncorrected fecal analysis results provided estimates of diet composition but did not provide proportions of ingested diet (Boertje et al. 1985; Russell et al. 1993). Unfortunately, a large percentage $(>80 \%)$ of the shrub particles were classified as "Other" or "Unknown", so we were not able to determine if they should be classified as evergreen or deciduous shrubs. Therefore we were unable to apply Russell et al.'s (1993) correction factor for digestibility. Paired t-tests were employed to identify significant changes in percent cover and diet between 1995/1996 and 2005. We calculated Ivlev's index of selectivity (Ivlev 1961) using the formula: (U-A) / (U+A), where $\mathrm{U}$ (utilization) was the amount of a vegetation type found in the fecal matter and A (availability) was the percent cover of that type found on the paired transect.

\section{Results}

The permanent vegetation transects indicated changes in vegetation from $1995 / 1996$ to 2005 in the winter range of the WAH. Significant declines in lichen abundance were noted, while both graminoids and shrubs increased during this time period (Table 1; Joly et al. 2007b).

The changes in vegetative cover were mirrored by changes in the paired fecal composition of WAH Caribou between 1995/1996 and 2005 (Table 2). The proportion of lichen found in the fecal pellets declined significantly $(\mathrm{T}=3.73, P<0.001$, $\mathrm{df}=23$ ), while the proportion of graminoids increased $(\mathrm{T}=3.53$, $P<0.0021$, df $=23$ ). The mean proportion of Cladina spp. declined from $21.8 \%$ to $15.2 \%$ from $1995 / 1996$ to 2005 ( $\mathrm{T}=4.71, P<0.001$, $\mathrm{df}=23)$. This decline in Cladina spp. represented $84 \%$ of the decline in overall lichen in fecal matter over this time period. There were no significant differences in the proportion of Cetraria spp., Cladonia spp., or non-preferred lichens (e.g., Alectoria spp., Bryoria spp., Peltigera spp., etc.) between 1995/1996 and 2005. There were no significant differences in the other vegetative classes (Table 2).

Lichens and mosses were found in the fecal matter of WAH Caribou more than they were present in the environment in both 1995/1996 and 2005 (Figure 1). Ivlev's (1961) index of selectivity increased for lichens between 1995/1996 and 2005, despite declines in lichen availability. The index decreased for mosses as its availability declined (Figure 1). Graminoids and shrubs were more common on the landscape than in the fecal matter of Caribou in both 1995/1996 and 


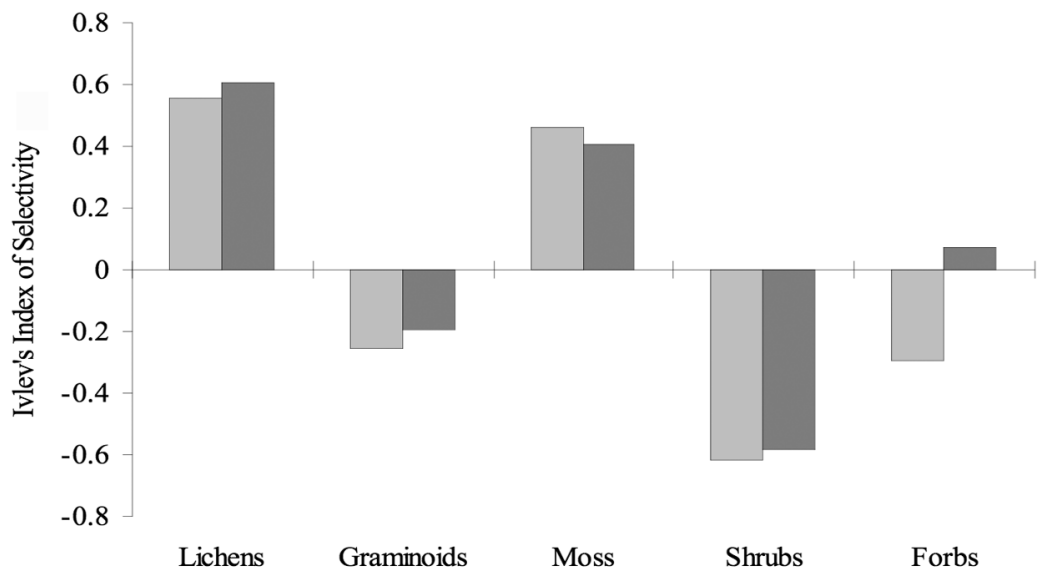

FIGURE 1. Ivlev's index of selectivity for Caribou utilizing different vegetative categories on the winter range of the Western Arctic Herd, northwestern Alaska, USA. Light-colored bars represent data from 1995/1996 and the dark bars from 2005. An index of 0 would occur when the amount of that category was found in equal percentages in the fecal matter and along paired permanent vegetation transects. Ratios $>0$ reveal vegetation types that were greater in the diet than found on the landscape. Ratios $<0$ reveal vegetation types that were less prevalent in fecal matter than on the landscape.

2005 (Figure 1). Ivlev's (1961) index of selectivity declined between 1995/1996 and 2005 in the face of increasing availability of these vegetation types.

\section{Discussion}

Lichen content in the winter diet of Caribou has been reported to be from $62-69 \%$ (Thompson and McCourt 1981; Boertje 1984; Boertje et al. 1985; Russell et al. 1993). While our results show somewhat lower lichen content $(51-59 \%)$, we were not able to apply correction factors to account for differential rate of digestibility among vegetation types. Lichen content is typically under-represented without correction factors (Russell et al. 1993), so our results are likely similar to these previous studies (though see Boertje et al. 1985).

We know of no other studies that have tracked the diets of Caribou over a decade and directly related detailed vegetative cover surveys to dietary analyses. Our results show that the recent winter diet of WAH Caribou contains less lichen and more graminoids than in the past, tracking changes in vegetative cover from $1995 / 1996$ to 2005 reported by Joly et al. (2007b). The percent of lichen in the fecal matter was $3.5-4$ times greater than the percent of lichen cover in the environment, suggestive of selection. Caribou used areas of high lichen cover more than other areas (Joly et al. 2007b). The significant reduction of Cladina spp. in the fecal matter between time periods was also reflected in declines of primary forage lichen on the landscape (Joly et al. 2007b). Grazing was likely a factor that drove the decline in lichen in northwest
Alaska (Joly et al. 2007b). It may take a couple of decades for lichens to recover from intense grazing, barring further disturbance (Henry and Gunn 1990).

Shrubs are significantly increasing in the Arctic (Sturm et al. 2001; Joly et al. 2007b); however, we did not detect a corresponding increase in shrubs in the diet of WAH Caribou. Shrub expansion could have negative impacts on individual Caribou energetics and multiplier effects on the herd (see Lawler and White 2006). Other researchers have reported increased moss cover where Caribou range has been heavily grazed (Klein 1987; van der Wal 2006), but changes in moss cover were not detected within the range of the WAH during this time period (Joly et al. 2007b). Mosses were present in the fecal matter in greater percentages than were found on the landscape; however we believe this is due to its low digestibility rather than Caribou selecting for this forage type (Boertje et al. 1985).

Climate warming is another factor that has been implicated in declining lichen cover within the range of the WAH (Joly et al. 2007b). Fire activity is strongly correlated with warm summer temperatures in Alaska and Canada (Duffy et al. 2005; Kasischke and Turetsky 2006). The frequency and extent of fires is predicted to increase due to global warming (Rupp et al. 2000; McCoy and Burn 2005). Lichens within the range of the WAH are slow to recover from wildfire, often taking many decades to recover to initial levels (Arseneault et al. 1997; Jandt et al. 2008). Overwintering Caribou are known to avoid burned areas in both tundra and boreal forest, in northwest Alaska, for up to 55 years (Joly et al. 2007a). Lack of lichens 
in these areas has been hypothesized to be a reason for this avoidance though other factors have been suggested (see review by Klein 1982).

Lichen cover has been declining in the study area since 1981 (Joly et al. 2007b). Potential outcomes of continued declines in lichen cover in winter range include range shifts and population-level effects (Ferguson et al. 2001; Joly et al. 2007b). Caribou nutritional status should not be assessed based on lichen abundance alone (Boertje 1990). Studies in the high Arctic studies have shown that Caribou can be less reliant on lichens (Thomas and Edmonds, 1983; Adamczewski et al. 1988). However, these Caribou do not face the predatory pressure and migratory expense that WAH Caribou do and also differ phenotypically. Additional differences between these types include greater ability of the high Arctic Caribou to store fat and digest graminoids and mosses (Tyler 1987). Large, migratory herds of barren-ground Caribou, like the WAH, are thought to be reliant on abundant terricolous lichens (White et al. 1981; Klein 1991; Heggeberget et al. 2002). Nevertheless, it has been suggested that Caribou may not be negatively affected by a change from a lichen-rich diet to a graminoid-rich diet as ecosystems transition to graminoid-dominated states (van der Wal 2006).

Adult survival rates would be the least sensitive population parameter to potential declines in nutritional status, so biologists and managers should monitor pregnancy rates and calf to cow ratios to detect early signs of nutritional stress. Declines in these parameters may imply that the nutritional status of the herd is declining due to poor range conditions and that the transition to a graminoid diet may impact the herd. Recruitment in the WAH has been slowly declining (Dau 2005a) and the most recent photo-census (2007) revealed a $20 \%$ decline in the herd (J. Dau, personal communication), which may be incipient indications of the importance of lichens to this herd. Predation is not likely a major factor in these declines with the herd size being so large and predator densities relatively low (Ballard et al. 1997; Haskell and Ballard 2007), though density-independent icing events may be a factor (Dau 2005b). Although the debate over the relative importance of lichens in the winter diet of Caribou remains unresolved, our results reveal that WAH Caribou use lichens extensively in the winter despite their declining abundance on the landscape in northwestern Alaska.

\section{Acknowledgments}

Fecal analysis was conducted by the Wildlife Habitat Nutrition Analysis Laboratory at Washington State University, Pullman, Washington, USA. R. Meyers, (retired) Bureau of Land Management, was an integral member of the research group during both study periods. We thank J. Lawler, D. Spalinger, J. Welker, S.
Wilson and two anonymous CFN reviewers for providing recommendations for substantially improving previous drafts of this manuscript.

\section{Literature Cited}

Adamczewski, J. Z., C. C. Gates, B. M. Soutar, and R. J. Hudson. 1988. Limiting effects of snow on seasonal habitat use and diets of caribou (Rangifer groenlandicus) on Coats Island, Northwest Territories, Canada. Canadian Journal of Zoology 66: 1986-1996.

Arsenault, D., N. Villeneuve, C. Boismenu, Y. Leblanc, and J. Deshaye. 1997. Estimating lichen biomass and caribou grazing on the wintering grounds of northern Quebec: an application of fire history and Landsat data. Journal of Applied Ecology 34: 65-78.

Ballard, W. B., L. A. Ayres, P. R. Krausman, D. J. Reed, and S. G. Fancy. 1997. Ecology of wolves in relation to a migratory caribou herd in northwest Alaska. Wildlife Monographs 135: 1-47.

Boertje, R. D. 1984. Seasonal diets of the Denali Caribou Herd, Alaska. Arctic 37: 161-165.

Boertje, R. D. 1990. Diet quality and intake requirements of adult female caribou of the Denali Herd, Alaska. Journal of Applied Ecology 27: 420-434.

Boertje, R. D., J. L. Davis, and P. Valkenburg. 1985. Uses and limitations of fecal analysis of Rangifer studies. Meredith, T. C. and Martell, A. M. eds. Caribou management, census techniques status in eastern Canada. Pages 307-316 in Proceedings of the Second North American Caribou Workshop, Val Morin, Quebec, 17-20 October 1984. McGill Subarctic Research Paper 40.

Chapin, F. S., III, G. R. Shaver, A. E. Giblin, K. J. Nadelhoffer, and J. A. Laundre. 1995. Responses of arctic tundra to experimental and observed changes in climate. Ecology 76: 694-711.

Cornelissen, J. H. C., T. V. Callaghan, J. M. Alatalo, A. Michelsen, E. Graglia, A. E. Hartley, D. S. Hik, S. E. Hobbie, M. C. Press, C. H. Robinson, G. H. R. Henry, G. R. Shaver, G. K. Phoenix, D. G. Jones, S. Jonasson, F. S. Chapin, U. Molau, C. Neill, J. A. Lee, J. M. Melillo, B. Sveinbjornsson, and R. Aerts. 2001. Global change and arctic ecosystems: is lichen decline a function of increases in vascular plant biomass? Journal of Ecology 89: 984-994.

Dau, J. 2005a. Western Arctic Herd. Pages 177-218 In: Caribou management report of survey and inventory activities, 1 July 2002-30 June 2004. Edited by C. Brown, Alaska Department of Fish and Game. Juneau, Alaska, USA.

Dau, J. 2005b. Two caribou mortality events in northwest Alaska: possible causes and management implications. Rangifer Special Issue 16: 37-50.

Duffy, P. A., J. E. Walsh, J. M. Graham, D. H. Mann, and T. S. Rupp. 2005. Impacts of large-scale atmosphericocean variability on Alaskan fire season severity. Ecological Applications 15: 1317-1330.

Ferguson, M. A. D., L. Gauthier, and F. Messier. 2001. Range shift and winter foraging ecology of a population of Arctic tundra caribou. Canadian Journal of Zoology 79: 746-758.

Hansen, J., R. Ruedy, J. Glascoe, and M. Sato. 1999. GIS analysis of surface temperature change. Journal of Geophysical Research 104: 30997-31022. 
Haskell, S. P., and W. B. Ballard. 2007. Modeling the Western Arctic Caribou Herd during a positive growth phase: potential effects of wolves and radiocollars. Journal of Wildlife Management 71: 619-627.

Heggberget T. M., E. Gaare, and J. P. Ball. 2002. Reindeer (Rangifer tarandus) and climate change: importance of winter forage. Rangifer 22:13-32.

Henry, G. H. R., and A. Gunn. 1990. Recovery of tundra vegetation after overgrazing by caribou in Arctic Canada. Arctic 44: 38-42.

Ivlev, V. S. 1961. Experimental ecology of the feeding of fishes. Yale University Press, New Haven, Connecticut, USA.

Jandt, R. R., K. Joly, C. R. Meyers, and C. Racine. 2008. Slow recovery of lichen on burned caribou winter range in Alaska tundra: potential influences of climate warming and other disturbance factors. Arctic, Antarctic, and Alpine Research 40: 89-95.

Joly, K., P. Bente, and J. Dau. 2007a. Response of overwintering caribou to burned habitat in northwest Alaska. Arctic 60: 401-410.

Joly, K., R. R. Jandt, C. R. Meyers, and M. J. Cole. 2007 b. Changes in vegetative cover on Western Arctic Herd winter range from 1981-2005: potential effects of grazing and climate change. Rangifer Special Issue 17: 199-207.

Kasischke, E. S., and M. R. Turetsky. 2006. Recent changes in the fire regime across the North American boreal region - spatial and temporal patterns of burning across Canada and Alaska. Geophysical Research Letters 33, L09703. 5 pages.

Klein, D. R. 1982. Fire, lichens, and caribou. Journal of Range Management 35: 390-395.

Klein, D. R. 1987. Vegetation recovery patterns following overgrazing by reindeer on St. Matthew Island. Journal of Range Management 40: 336-338.

Klein, D. R. 1991. Limiting factors in caribou population ecology. Rangifer Special Issue 7: 30-35.

Lawler, J. P., and R. G. White. 2006. Effect of browse on post-ingestive energy loss in an Arctic ruminant: implications for muskoxen (Ovibos moschatus) in relation to vegetation change. Canadian Journal of Zoology 84:1657-1667.

Messier, F., J. Huot, D. LeHenaff, and S. Luttich. 1988. Demography of the George River Herd: evidence of population regulation by forage exploitation and range expansion. Arctic 41: 279-287.

Moser, T. J., T. H. Nash, III, and J. W. Thomson. 1979. Lichens of Anaktuvuk Pass, Alaska, with emphasis on the impact of caribou grazing. Bryologist 82: 393-408.

McCoy, V. M., and C. R. Burn. 2005. Potential alteration by climate change of the forest-fire regime in the boreal forest of central Yukon Territory. Arctic 58: 276-285.

Parker, K. L., P. S. Barboza, and T. R. Stephenson. 2005. Protein conservation in female caribou (Rangifer taran$d u s$ ): effects of decreasing diet quality during winter. Journal of Mammalogy 86: 610-622.

Rupp, T. S., F. S. Chapin, III, and A. M. Starfield. 2000. Response of the subarctic vegetation to transient climatic change on the Seward Peninsula in north-west Alaska.
Global Change Biology 6: 541-555.

Russell, D. E., A. M. Martell, and W. A. C. Nixon. 1993. Range ecology of the Porcupine Caribou Herd in Canada. Rangifer Special Issue 8: 1-168.

Serreze, M. C., J. E. Walsh, F. S. Chapin, III, T. Osterkamp, M. Dyurgerov, V. Romanovsky, W. C. Oechel, J. Morison, T. Zhang, and R. G. Barry. 2000. Observational evidence of recent change in the northern high-latitude environment. Climatic Change 46: 159-207.

Smith, L. C., Y. Sheng, G. M. MacDonald, and L. D. Hinzman. 2005. Disappearing arctic lakes. Science 308: 1429.

Sturm, M., C. Racine, and K. Tape. 2001. Increasing shrub abundance in the Arctic. Nature 411: 546-547.

Thomas, D. C., and E. J. Edmonds. 1983. Rumen contents and habitat selection of Peary caribou in winter, Canadian Arctic Archipelago. Arctic and Alpine Research 15: 97-105.

Thompson, D. C., and K. H. McCourt. 1981. Seasonal diets of the Porcupine Herd. American Midland Naturalist 105: 70-76.

Tyler N. J. C. 1987. Body composition and energy balance of pregnant and non-pregnant Svalbard reindeer during winter. Symposia of the Zoological Society of London 57: 203-229.

Valkenburg, P. 1994. Investigation and improvement of techniques for monitoring recruitment, population trend, and nutritional status in the Western Arctic Caribou Herd. Research progress report. Alaska Department of Fish and Game. Federal Aid in Wildlife Restoration Project W-242, Study 3.40. Juneau, Alaska, USA. 20 pages.

van der Wal, R. 2006. Do herbivores cause habitat degradation or vegetation state transition? Evidence from the tundra. Oikos 114: 177-186.

Walker, M. D., C. H. Wahren, R. D. Hollister, G. H. R. Henry, L. E. Ahlquist, J. M. Alatalo, M. S. BretHarte, M. P. Calef, T. V. Callaghan, A. B. Carroll, H. E. Epstein, I. S. Jonsdottir, J. A. Klein, B. Magnusson, U. Molau, S. F. Oberbauer, S. P. Rewa, C. H. Robinson, G. R. Shaver, K. N. Suding, C. C. Thompson, A. Tolvanen, Ø. Totland, P. L. Turner, C. E. Tweedie, P. J. Webber, and P. A. Wookey. 2006. Plant community responses to experimental warming across the tundra biome. Proceedings of the National Academy of Science 103: 1342-1346.

White, R. G. 1983. Foraging patterns and their multiplier effects on productivity of northern ungulates. Oikos 40: 377-384.

White R. G., F. L. Bunnell, E. Gaare, T. Skogland, and B. Hubert. 1981. Ungulates on arctic ranges. Pages 397-483 in Tundra ecosystems: a comparative analysis. Edited by L. C. Bliss, O. W. Heal and J. J. Moore, Cambridge: Cambridge University Press.

Received 4 July 2007

Accepted 20 August 2008 